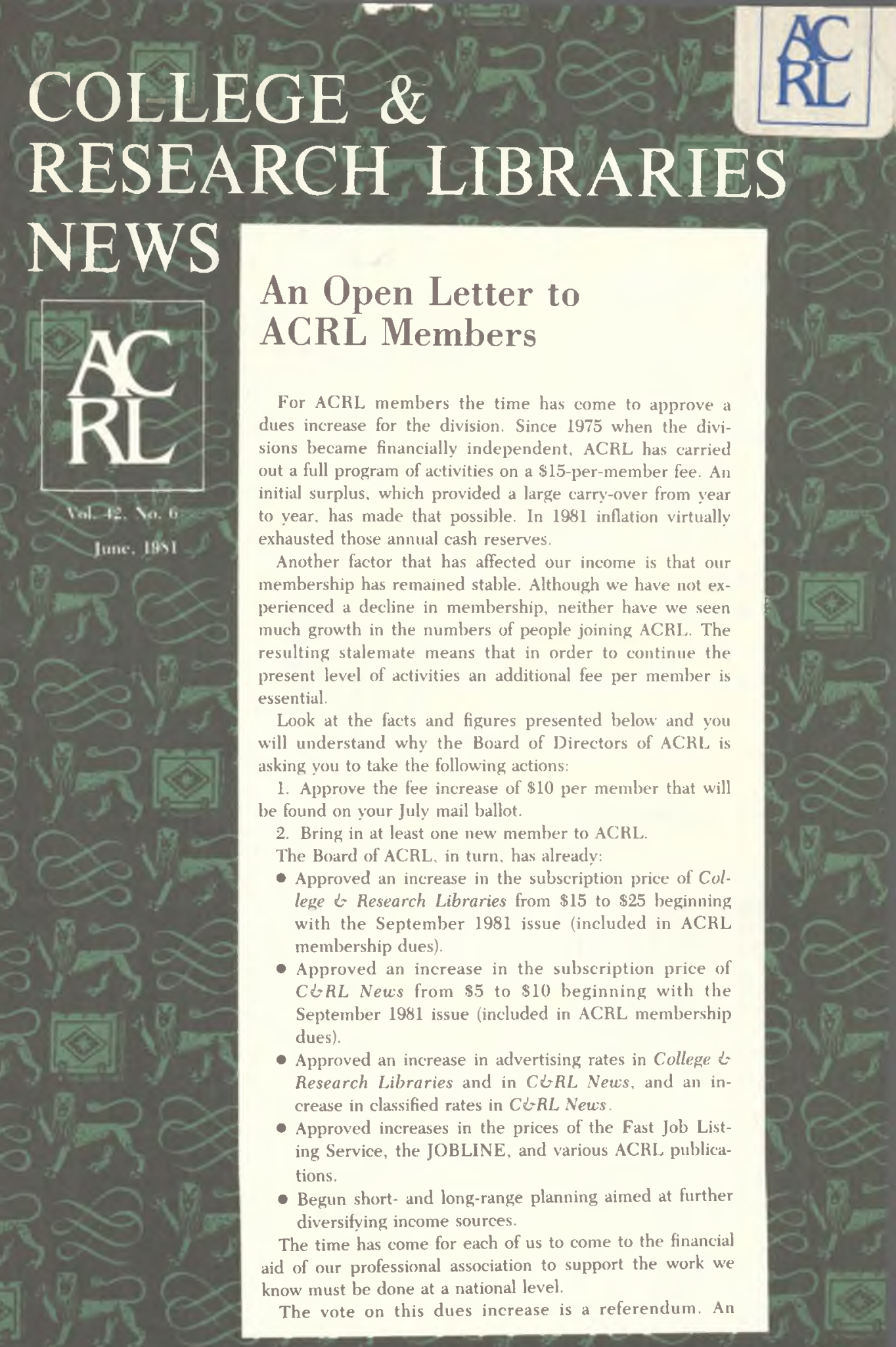


In this issue:

\section{An Open Letter to}

ACRL Members . . . . . . 165

Academic Status Survey..... 171

A Conversation with

David Weber

Bibliographic Instruction:

A Non-Credit/Non-Graded

Course at the University

of Kansas . . . . . . . 173

News from the Field. . . . . . 180

People . . . . . . . . . . . . 182

Publications ........... 188

Calendar. . . . . . . . . . 193

Classified Advertising . . . . . . 195 affirmative vote is a vote for maintaining the services ACRL currently provides. A negative vote is a vote for retrenchment-a sharp reduction in support of membership activities and services. If you believe as I do that the issues and opportunities which academic librarians face in the future require a strong role for ACRL, you will join me in voting for a dues increase. I urge you to do so.-Millicent D. Abell, President, ACRL.

\section{QUESTIONS AND ANSWERS ON ACRL Financial MatTers}

- How many members are there and how has ACRL grown? While ACRL programs have grown and membership participation has increased, total membership has not grown (except for an increase at the time of the Boston conference) and appears to have reached a plateau (Table 1).

\section{TABLE 1}

$\begin{array}{cr}\text { ACRL MEMBERSHIP, } & 1976-1981 \\ 1976 & 8,473 \\ 1977 & 8,609 \\ 1978 & 8,600 \\ 1979 & 8,904 \\ 1980 & 8,915 \\ 1981 & 8,991\end{array}$

- Why are my dues being spent on new services which I don't want? Most of the new services are self-supporting and even contribute money to the ACRL general fund. It is the component of ACRL costs which provides basic membership service that now costs more. Because of inflation over the past seven years and the need to find other revenue sources, membership dues now contribute a smaller percentage of revenues than in the past. Other sources of income have been needed to supplement the income from membership dues. These other sources include publications, JOBLINE, Fast Job Listing Service, gifts, national conference, and continuing education activities (see Table 2).

- What is the pattern of ACRL expenditures? Below is a table which shows ACRL revenues and expenditures over the last six years. ACRL has sometimes had a surplus but as membership demands have grown, this surplus has been used to cover the deficit and in the 18 months ahead expenses will so far exceed revenues that the surplus will be entirely expended (see Table 3 ).

- What happened to the surplus from the Boston conference? The total surplus from the Boston conference was $\$ 63,000$. Of this, $\$ 40,000$ was for uncharged staff time. This $\$ 40,000$ has been used as seed money for the staff time for the Minneapolis conference. The remaining $\$ 23,000$ has been available for ACRL activities. It is not 
TABLE 2

SOURCES OF ACRL INCOME

\begin{tabular}{lrrrrrr} 
& \multicolumn{1}{c}{$\mathbf{7 5 / 7 6}$} & \multicolumn{1}{c}{$\mathbf{7 6 / 7 7}$} & \multicolumn{1}{c}{$\mathbf{7 7 / 7 8}$} & \multicolumn{1}{c}{$\mathbf{7 8 / 7 9}$} & \multicolumn{1}{c}{$\mathbf{7 9 / 8 0}$} & \multicolumn{1}{c}{$\mathbf{8 0 / 8 1}$} \\
\hline Membership & $\$ 91,980$ & $\$ 100,652$ & $\$ 114,447$ & $\$ 127,308$ & $\$ 125,093$ & $\$ 121,445$ \\
C $\boldsymbol{R} \boldsymbol{R L}$ & 49,894 & 53,804 & 70,676 & 80,685 & 87,760 & 88,814 \\
CむRL News & $\mathbf{2 2 , 9 7 4}$ & 25,034 & 25,236 & 25,051 & 34,218 & 37,448 \\
Other & 20,041 & 25,191 & 3,914 & 8,102 & 78,985 & 92,174 \\
\hline \multicolumn{1}{c}{ Total } & 184,889 & 204,681 & 214,273 & 241,146 & 326,056 & 339,881 \\
\hline
\end{tabular}

planned to use these conferences as significant money-making enterprises since to do so would raise the registration fees to attendees and defeat ACRL's purpose for having conferences.

- Why doesn't ACRL seek other sources of income? ACRL is actively exploring other sources of income. Already some success has been achieved (see Table 2) but more needs to be done. A dues increase will stabilize our finances and give us time to actively explore alternative sources of revenue.

Despite inflation ACRL has not raised its dues of living increase over the past five years, and an operating reserve. The first is a budget without a dues increase, but it does include revenue increases attributable to changes in advertising rates in $C \& R L$ and $C \& R L$ News, classified advertising rates, subscription prices, and ACRL products and services (JOBLINE, Fast Job Listing Service, publications, etc.). The second includes a dues increase of $\$ 10$ per member.

- What happens if the dues increase fails? In the short run, that is for the year 1981/82, the direct support to committees, chapters, and sec-

\section{TABLE 3}

InCOME AND EXPENSE PATTERN

\begin{tabular}{|c|c|c|c|c|c|c|c|}
\hline & $75 / 76$ & $76 / 77$ & $77 / 78$ & 78/79 & $79 / 80$ & $80 / 81$ & $81 / 82$ \\
\hline $\begin{array}{l}\text { Surplus carried } \\
\text { forward }\end{array}$ & - & $\$ 5,103$ & $\$ 41,619$ & $\$ 78,420$ & $\$ 110,913$ & $\$ 135,623$ & $\$ 71,000$ \\
\hline Income & 184,889 & 204,681 & 214,273 & 241,146 & 326,056 & 339,881 & 430,000 \\
\hline Expense & 180,676 & 188,489 & 193,522 & 230,401 & 301,346 & 404,430 & 501,000 \\
\hline $\begin{array}{l}\text { Closing income } \\
\text { transfers }\end{array}$ & 890 & 20,324 & 16,050 & 21,748 & - & - & - \\
\hline Balance & 5,103 & 41,619 & 78,420 & 110.913 & 135,623 & 71,074 & 0 \\
\hline
\end{tabular}

for seven years, although ALA did so in 1980 . ACRL can no longer avoid this and still furnish the basic member services.

- What is the present state of the budget? Two budgets have been drawn up (see Table 4). Both include reserves for the first time: a salary reserve for staff which has not had a significant cost tions will have to be cancelled. The Continuing Education and the Bibliographic Instruction programs will have to be terminated or curtailed. These are the only non-revenue producing services which can be readily singled out of the budget.

In the longer run, the ACRL office could be

TABLE 4

1981/82 BUDGET WITH AND

WITHOUT DUES INCREASE

Budget 1

Budget 2

Income

Expense

Balance

Surplus carried forward

Salary reserve

Operating reserve

Final surplus
No Dues increase

Dues Increase

\begin{tabular}{c}
$\$ 430,000$ \\
454,000 \\
\hline$(24,000)$ \\
71,000 \\
$(20,000)$ \\
$(27,000)$ \\
\hline 0
\end{tabular}

480,000

8,000

71,000

20,000

30,000

29,000 
restructured in a more truncated form and further savings realized by reducing staff; but this would result in a sharp reduction in membership services.-Richard Talbot, ACRL Budget and Finance Committee Chair.

\section{College Standards Survey}

A four-page summary of the results of a 1980 survey on The Use and Effectiveness of the 1975 "Standards and Guidelines for College Libraries" (C\&RL Neus, October 1975) is now available from ACRL/ALA, $50 \mathrm{E}$. Huron St., Chicago, IL 60611 . The summary may be ordered free of charge to ACRL members and for $\$ 1$ to non-members. All orders should include a self-addressed mailing label and $30 \propto$ in postage.

\section{CONTINUE YOUR EDUCATION}

Enrollment is still open in ACRL's five Continuing Education courses, offered this month in conjunction with the ALA annual meeting in San Francisco. The $\mathrm{CE}$ courses, ranging from one to three days in length, cover the following areas of interest:

CE 1-The Librarian as Consultant offers a comprehensive view of the major aspects of consultation and provides participants with the knowledge and skills to interact effectively with clients. Such skills can be valuable to specialists, managers, organization leaders, and program directors whether they are external or internal consultants. The instructor is Jim Ekendahl of Consulting Concepts, Inc, Seattle. The course will be held Thursday-Friday, June 25-26, 9:00 a. $\mathrm{m} .-500$ p.m.

CE 2-Planning and Procuring a Library Turnkey System will work through the process whereby an academic library manager can assess the potentials for, determine needs, and design a process for procuring a turnkey automated library system. Each participant will be contacted in advance of the course by the instructors, Rob McGee and Howard Dillon of RMG Consultants, Inc., Chicago, for information pertaining to their institution and its needs. The course will be held Thursday-Friday, June 25-26, from 9:00 a.m.5:00 p.m.

CE 3-Effective Supertisory Skills introduces techniques for effective supervision, such as evaluating progress, determining and scheduling completion dates, and maintaining an interim report system. Discussion topics include under-

\section{Current Awareness Alert}

Current awareness services to library professionals is the topic of a study by ALA's Library and Information Literature Membership Initiative Group. This group has established a Task Force on Information Needs of the $\mathrm{Li}$ brary Profession that wishes to hear from anyone involved in offering a current awareness service to library and information professionals. Any program which updates individuals on recent professional literature and trends would be of interest, including table-ofcontents services, newsletters specifically for current awareness purposes, and presentations on new developments in the literature. Information should be sent to: Patricia Tegler, Library Studies/Communications Librarian, Lockwood Library, SUNY at Buffalo, Buffalo, NY 14260

standing the people supervised, responsibilities of the supervisor, and techniques of supervision. The instructor for the course is Herbert $S$ White, dean and professor, Graduate School of Library and Information Science, Indiana University. It will run Friday, June 26, from 9:00 a.m. $-5: 00$ p.m.

CE 4 -Career Planning for the Academic $\mathrm{Li}^{-}$ brarian will review factors that influence career development, explore alternative methods of career planning, apply techniques to help determine career goals and objectives, review methods for putting career plans into effect, and discuss obstacles to implementing career plans. Participants should be academic librarians with two or more years of library experience. Course instructor Keith Russell is a program associate with the Council on Library Resources, Washington, DC. The course will be held Friday, June 26, from 9:00 a.m. $-5: 00$ p.m.

CE 5-Basic Archives Management for Librarians, co-sponsored by the Society of American Archivists, will inform librarians about basic archival functions. Enrollment is open to librarians with little or no formal archival education. Course instructors are David Horn, university archivist, DePauw University, and Megan Floyd Desnoyers, Kennedy Library, National Archives, Boston. The course will be held Wednesday-Friday, June 24-26, from 9:00 a.m.-5:00 p.m.

Advance registration is required and attendance will be strictly limited. Four of the five CE courses will be held at the Civic Auditorium in San Francisco; CE 5 will be held at the SheratonPalace. For further registration information, contact: C. Brigid Welch, ACRL/ALA, $50 \mathrm{E}$. Huron St., Chicago, IL 60611; (312) 944-6780. 


\title{
REGISTRATION FORM
}

\author{
PRECONFERENCES AND \\ CONTINUING EDUCATION COURSES
}

\section{PLEASE PRINT}

Name LAST

FIRST

Phone (office) ( )

Mailing address

STREET

CITY

STATE

ZIP

Institutional affiliation (to appear on badge)

PLEASE CIRCLE THE APPROPRIATE DOLLAR AMOUNT

FOR THE COURSE OF YOUR CHOICE

\begin{tabular}{llrr} 
Course & & ACRL Member & Non-member \\
\hline CE 1 & Librarian as Consultant (2 days) & $\$ 160$ & $\$ 180$ \\
CE 2 & $\begin{array}{l}\text { Planning and Procuring a Turnkey Library System } \\
\text { (2 days) }\end{array}$ & 145 & 165 \\
CE 3 & Effective Supervisory Skills (1 day) & 75 & 95 \\
CE 4 Career Planning for the Academic Librarian (1 day) & 75 & 95 \\
CE 5 & Basic Archives Management for Libraries (3 days) & 195 & 220 \\
PC 1 & $\begin{array}{l}\text { Views and Approaches to Bibliographic Instruction } \\
\text { (includes housing and meals) (2⿺辶2 days) }\end{array}$ & 115 & 140 \\
PC 2 & $\begin{array}{l}\text { The Impact of the New Technology on LRC Programs } \\
\text { (2 days) }\end{array}$ & 95 & 115 \\
PC 3 & $\begin{array}{l}\text { The Collection Builders: Booksellers, Book Collectors, } \\
\text { Librarians (31/2 days) }\end{array}$ & 140 & 180 \\
& *Late registration fee & 15 & 15
\end{tabular}

\section{ENTER TOTAL AMOUNT ENCLOSED}

*Fee for registration after May 15 (applies to PC 1-3 only).

CONFIRMATION: Written confirmations will be made

CANCELLATIONS: Written notice of cancellations received by June 1 will be honored subject to a $\$ 20$ cancellation charge. No refunds for cancellations received after June 1 .

Mail this form and your check to:

REGISTER EARLY
Association of College and Research Libraries

50 E. Huron St.

Chicago, IL 60611

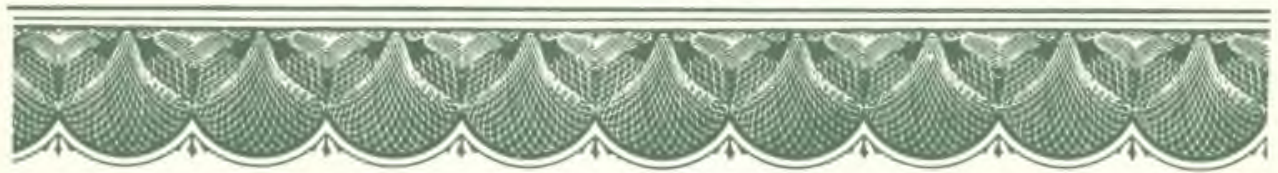




\section{YOU CAN SAVE $\$ 6,000$ THIS YEAR}

By converting your subscription to the British House of Commons Parliamentary Papers for 1980/81 from the full size edition (which is costing you over $\$ 7,000$ ) to our microfiche edition which costs $\$ 1,175$.

Save time. The microfiche edition is sent monthly by airmail direct from the $\mathrm{UK}$ and arrives earlier than the printed edition.

Save space. The microfiche edition saves expensive shelf space.

Many large libraries have released substantial funds for other purchases by converting to the microfiche edition. So can you to make the maximum saving this year please send us your order or request for more information as soon as possible.

\section{CATALOGUE OF BRITISH OFFICIAL PUBLICATIONS NOT PUBLISHED BY HMSO NOW AVAILABLE 1980 ANNUAL VOLUME 1981 FIRST BI-MONTHLY ISSUE}

\section{0: $\$ 190$ 1981: 6 issues and annual cumulation $\$ 260$}

This important new reference book catalogs and indexes for the first time the thousands of official publications published by over 280 Government departments, nationalised industries, research institutes and 'quangos' that are not published by HMSO, and are not listed in the British National Bibliography or any other bibliography.

You will now have access to publications of institutions such as the Foreign Office, the Home Office, and the Bank of England, of which at present you are not even aware.

The publications themselves are available from us on inexpensive diazo or silver microfiche; individually, by publishing body, or in subject sets.

Send orders and requests for information to:

Somerset House, 417 Maitland Avenue, Teaneck, NJ 07666 Telephone: 201 833-1795 